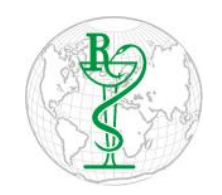

INDO GLOBAL JOURNAL OF

PHARMACEUTICAL SCIENCES

ISSN 2249- 1023

\title{
Survey of Medicinally Important Weeds of Daund Tahsil from Pune District (M.S.), India
}

\author{
Bagal J.G \\ Department of Botany, E. S. Divekar College, Varvand, Tal. Daund, Dist. Pune -412215. (M.S.), India
}

Address for Correspondence: Bagal J.G., bagaljalindar@ rediffmail.com

\begin{abstract}
Received:
01.02.2019

Accepted:

15.07.2019

Keywords

Medicinal Plants,

Daund Tahsil,

Weeds, Survey.
\end{abstract}

\begin{abstract}
The dependence of man on plant resources especially for the medicinal purposes is as old as the human civilization. Weeds can be defined as the plant growing in the wrong places from farmer's point of view. In contrast to the cultivated plants, the weed is the invader and uninvited guest in any agricultural fields. Weeds are an excellent example of the successful struggle for existence. The invasive weeds infesting the crop fields and other ecosystems have become a serious problem today. The agro ecosystems show association of various types of native and invasive weeds in crop plants. They are harmful as well as useful. Fortunately majority of weeds are not harmful to cultivated plants with which they are associated. The present paper focuses on medicinally important weeds collected from Daund Tahsil from Pune district (M.S.). Daund Tahsil lies in Pune district extend from $18^{\circ} 18^{\prime}$ to $18^{\circ} 41^{\prime}$ North Latitude and $74^{\circ} 7^{\prime}$ to $74^{\circ} 51^{\prime}$ East Longitude, covering an area of $1289.86 \mathrm{Sq} . \mathrm{Km}$. (128986 hector) and elevation of 548 meters above MSL. Total 25 weed species belongs to 16 families with their medicinal importance are recorded. Instead of using weedicides for their eradication, weeds can uproot and instead of throwing them they may be used for medicinal purposes. (C) 2019 iGlobal Research and Publishing Foundation. All rights reserved.
\end{abstract}

Cite this article as: Bagal, J.G. Survey of medicinally important weeds of Daund tahsil from Pune district (M.S.), India. Indo Global J. Pharm. Sci., 2019; 9(2): 69-72. DOI: http://doi.org/10.35652/IGJPS.2019.9203 .

\section{INTRODUCTION}

No plant is useless in the nature. Plants have been, and still are a rich source of many natural products. In India, most of which have been used for traditional human health care systems viz. Ayurveda, Unani, and Siddha. The dependence of man on plant resources especially for the medicinal purposes is as old as the human civilization. People throughout the world have use medicinal plants and have great faith on their effectiveness due their inherent medicinal properties. Many weeds contain chemical compounds which are biologically active and potentially useful for medical sciences. There is also good biochemical evidence, which supports the hypothesis that plants in disturbed areas are likely to have more chemicals in them for defense. Fortunately majority of weeds are not harmful to cultivated plants with which they are associated.

Weed is a plant growing where it is not desired. Weeds can be defined as the plant growing in the wrong places from farmer's point of view. In contrast to the cultivated plants, the weed is the invader, an uninvited guest in any agricultural fields. Weeds are an excellent example of the successful struggle for existence. Weed flora of agricultural fields has large ecological amplitude, so they multiply and flourish well even in changed environmental conditions. The invasive weeds infesting the irrigated and non-irrigated agricultural fields and other ecosystems, the associations of various types 
Indo Global Journal of Pharmaceutical Sciences, 2019; 9(2): 69-72

of native and invasive weeds in crops and barren lands have become a serious problem today.

Daund Tahsil lies in Pune district situated on the margins of Bhima River. Daund Tahsil consists of 102 villages and one urban centre. Geographically this region extends from $18^{\circ} 18^{\prime}$ to $18^{\circ} 41^{\prime}$ North Latitude and $74^{\circ} 07^{\prime}$ to $74^{\circ} 51^{\prime}$ East Longitude (Map-1). The geographical area of the study region is 1289.86 Sq.Km. (128986 hector) according to 2011 census. The average height of study area is 554 meters from mean sea level. The river Bhima and its tributary rivers Mula-Mutha are dominating drainage pattern in study region. Agriculture is predominant in Daund tahsil and it provides livelihood to $66.93 \%$ population. Sugarcane is one of the important cash crops in Daund tahsil. Total area under cultivation is 103844.94 hectares in Daund tahsil. The present work revealed that the medicinally important weeds of agricultural fields of Daund Tahsil from Pune district. Instead of using weedicides for their eradication, weeds can uproot and instead of throwing them they may be used for medicinal purposes.

The earlier studies on weed flora and their medicinal uses have been made by different workers (Adlakha, P. A. et al., 1971; Bhattacharya et al., 2008; Mulay J. R. \& Sharma P. P. 2012; Oudhia P. 2001; Sahu P. K. et al., 2010; Deokule S. S. \& Kamble S. Y. 1984; Chakravarti, A.K. 1957; R. Rex Immanuel \& L. Lyla Elizabeth, 2009; Prayaga M. P. et al., 2011.), from different parts of India.

\section{Map-1: Geographical location of Pune District in Maharashtra State (India) and Daund Tahsil Pune district.}

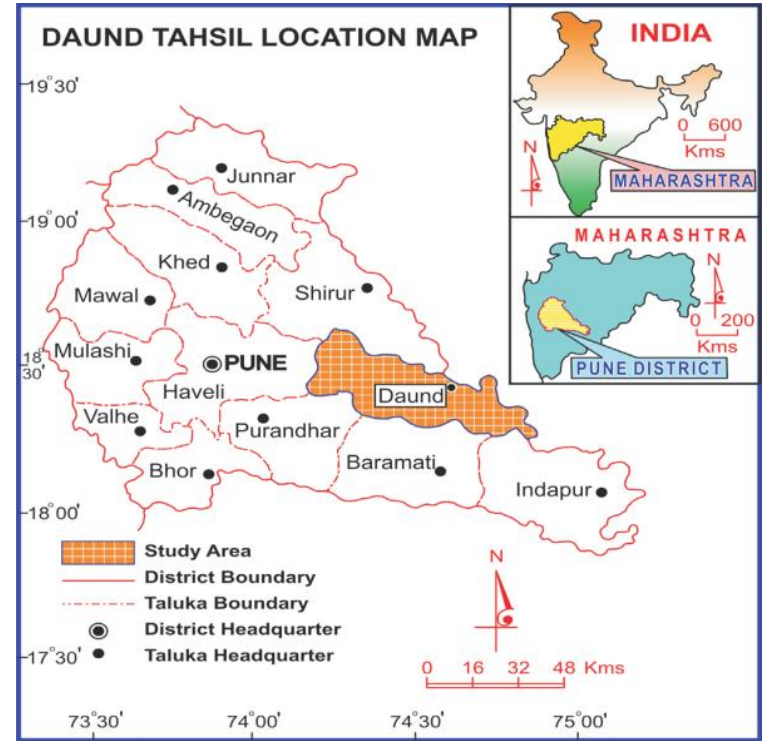

\section{MATERIALS \& METHODS}

The exploration of the area under study includes the planned study tours to various places for crop weed species collection. It was carried out during 2014-2017. Several daily and seasonal field tours were made to cover the entire Daund Tahsil. Information on the medicinal importance of different parts of the weed species against various disorders was collected by the traditional peoples of the study area. Herbariums of the medicinal weed species were prepared (Jain, S. K. \& Rao, R. 1960). The specimens were identified by comparing with the authentic specimens of Botanical survey of India. Western circle, Pune, Herbarium of Department of Botany, Savitribai Phule Pune University, Pune.

Later these identifications were checked with the help of flora's, monographs and relevant published literature. Each weed species was studied and identified using the 'Flora of British India'. (Hooker, J. D. 1872-1897); 'Flora of Presidency of Bombay' (Cooke, T. 1901-1908; Repr.1958.); Flora of Maharashtra State - Dicotyledones (Vol-1) (Singh, N. P. et al. 2000); Flora of Maharashtra State - Dicotyledons Vol-2. (Singh, N. P. et al., 2001); 'Flora of Maharashtra State Monocotyledons'. (Sharma, B. D. 1996); 'Flora of Baramati' (Bhagat, R.B. et al., 2008).

\section{RESULTS AND DISCUSSION}

Following are the medicinal uses of weed species with their scientific names, name of the family, local or common names and their medicinal importance. These weeds are arranged in alphabetical order (Refer Table 1).

The present investigation revealed that total 25 weeds belonging to 16 families were found medicinally important (Table-1). Of which 15 families are of Dicots and one family that of Monocot. The major species used are from familiesAsteraceae (5), Solanaceae (4), Amaranthaceae (2) and Caesalpinnaceae (2). Weeds are one of the major deterrents in sustaining the crop productivity. The weed control problem is major challenge to the farmers because of increasing labor cost. However different parts of the weeds are very useful in various disorders. Therefore before throwing them, we can study the medicinally important aspect of the weeds. These weeds can become an additional source of income for farmers, if they are made aware about the medicinal utilities of these weeds. 
Indo Global Journal of Pharmaceutical Sciences, 2019; 9(2): 69-72

Table-1: List of Medicinally Important Weeds of Daund Tahsil from Pune District

\begin{tabular}{|c|c|c|c|c|}
\hline Sr.No & Botanical Name & Family & Common Name & Medicinal Importance \\
\hline 1 & $\begin{array}{l}\text { Achyranthes aspera } \\
\text { Linn. }\end{array}$ & Amaranthaceae & 'Aghada' & $\begin{array}{l}\text { Leaf paste is useful in skin diseases and piles. Decoction of plant } \\
\text { part is used for treating rheumatism and joint pains. Root paste is } \\
\text { applied externally on scorpion sting. The whole plant is used in } \\
\text { toothache. }\end{array}$ \\
\hline 2 & $\begin{array}{l}\text { Ageratum conyzodies } \\
\text { L. }\end{array}$ & Asteraceae & 'Sahdevi, Osadi' & $\begin{array}{l}\text { Decoction of leaf is applied on cuts, wounds and burns. Leaf } \\
\text { juice is also used in skin diseases, scabies and uterine disorders. }\end{array}$ \\
\hline 3 & $\begin{array}{l}\text { Argemone mexicana } \\
\text { Linn. }\end{array}$ & Papavaraceae & 'Pivala Dhotra' & $\begin{array}{l}\text { Seeds are used in asthma, cough and headache. The latex is } \\
\text { applied externally for healing wounds, swellings and body pains. } \\
\text { The leaf paste is used in ulcers and leprosy. }\end{array}$ \\
\hline 4 & $\begin{array}{l}\text { Asclepias currasavica } \\
\text { L. }\end{array}$ & Asclepiadaceae & 'Haldi kunku'. & Root extract given to children for eradication of intestinal worms. \\
\hline 5 & $\begin{array}{l}\text { Boerhhavia erecta } \\
\text { Linn. }\end{array}$ & Nyctaginaceae & Punamava' & $\begin{array}{l}\text { The whole plant is used in headache. Leaf decoction is taken for } \\
\text { kidney stone and other urinary disorders. Leaf is given for } \\
\text { purification of blood. The roots are given for asthma, cough and } \\
\text { fever. }\end{array}$ \\
\hline 6 & Cassia sophera L. & Ceasalpiniaceae & 'Chilhar'. & Leaves are applied externally over joints in treating arthritic pain. \\
\hline 7 & Cassia tora Linn. & Ceasalpiniaceae & 'Takla' & $\begin{array}{l}\text { Leaf juice is used in cuts, boils, burns and as antiseptic treatment. } \\
\text { Seeds are given in stomach disorders. }\end{array}$ \\
\hline 8 & Celosia argentea Linn. & Amaranthaceae & 'Kurdu.' & $\begin{array}{l}\text { Seed powder is given with sugar for fever. The plant is also used } \\
\text { to cure urinary stone, diarrhea. }\end{array}$ \\
\hline 9 & $\begin{array}{l}\text { Centella asiatica (L.) } \\
\text { Urb }\end{array}$ & Apiaceae & 'Mandukapami' & $\begin{array}{l}\text { The decoction of plant is given in treating burning sensation } \\
\text { while urination. }\end{array}$ \\
\hline 10 & $\begin{array}{l}\text { Chenopodium album } \\
\text { L. }\end{array}$ & Chenopodiaceae & 'Chakwat'. & Leaves used for treating anemia. \\
\hline 11 & $\begin{array}{l}\text { Cuscuta reflexa } \\
\text { Roxb. }\end{array}$ & Cuscutaceae & 'Amarvel' & $\begin{array}{l}\text { The whole plant is used to prepare paste, which is applied } \\
\text { externally on joint pains, rheumatism and inflammations. }\end{array}$ \\
\hline 12 & $\begin{array}{l}\text { Cynodon dactylon } \\
\text { (L.) Pers. }\end{array}$ & Poaceae & $\begin{array}{l}\text { 'Harali, Barmoda } \\
\text { Grass, }\end{array}$ & $\begin{array}{l}\text { The whole plant is used in ulcers in stomach. Leaf paste is } \\
\text { applied for piles and in vomiting. }\end{array}$ \\
\hline 13 & $\begin{array}{l}\text { Datura stramonium } \\
\text { Linn. }\end{array}$ & Solanaceae & 'Dhotara' & $\begin{array}{l}\text { The dried leaves are source of drug 'stramonium'. It is used in } \\
\text { treatment of asthma. The plant is chief constituent of ayurvedic } \\
\text { preparation 'Kanaka Asava'. }\end{array}$ \\
\hline 14 & Euphorbia hirta Linn. & Euphorbiaceae & 'Dudhani' & $\begin{array}{l}\text { Leaf juice is applied on wounds, treatment for snake bite and } \\
\text { scorpion bite. }\end{array}$ \\
\hline 15 & $\begin{array}{l}\text { Evolvulus aslinoides } \\
\text { (L.) Linn. }\end{array}$ & Convolvulaceae & 'Shankhapushpi' & The leaves are given in asthma, bronchitis and ulcers. \\
\hline 16 & Lagascea mollis Cav. & Asteraceae & --- & Decoction of leaves given in cuts and wounds. \\
\hline 17 & $\begin{array}{l}\text { Launaea procumbens } \\
\text { (Roxb.) Ramayya }\end{array}$ & Asteraceae & 'Pathri' & $\begin{array}{l}\text { Dried leaf powder is given for kidney stone. The roots are used to } \\
\text { cure urinary disorders. }\end{array}$ \\
\hline 18 & $\begin{array}{l}\text { Parthenium } \\
\text { hysterophorus Linn. }\end{array}$ & Asteraceae & $\begin{array}{l}\text { 'Congress, Gajar } \\
\text { Gavat }\end{array}$ & Flowers are useful in cold and bronchitis. \\
\hline 19 & Sida acuta Burm. & Malvaceae & $\begin{array}{l}\text { 'Bala, Chikana, } \\
\text { Tupkadi' }\end{array}$ & $\begin{array}{l}\text { Roots useful for the treatment of nervous and urinary disorders, } \\
\text { fever and stomach complaints. Flower paste is given in boils and } \\
\text { burns. Leaf is given in gastric disorders and stomach pains. }\end{array}$ \\
\hline 20 & $\begin{array}{l}\text { Solanum } \\
\text { Linn. }\end{array}$ & Solanaceae & 'Kanguni' & $\begin{array}{l}\text { Fruits are used in fever, diarrhea, and eye diseases. The juice of } \\
\text { the plant is used in bleeding of piles. }\end{array}$ \\
\hline 21 & $\begin{array}{l}\text { Solanum virginianum } \\
\text { Linn. }\end{array}$ & Solanaceae & 'Bhui Ringani' & The fruits are used in asthma, cough and bronchitis. \\
\hline 22 & $\begin{array}{l}\text { Tephrosia purpurea } \\
\text { (L.) Pres. }\end{array}$ & Fabaceae & $\begin{array}{l}\text { 'Sharpunkha, } \\
\text { Unhali' }\end{array}$ & $\begin{array}{l}\text { The roots are used to cure kidney stone. The whole plant powder } \\
\text { is used to treat Jaundice. }\end{array}$ \\
\hline 23 & $\begin{array}{l}\text { Tribulus terestris } \\
\text { Linn. }\end{array}$ & Zygophylaceae & $\begin{array}{l}\text { 'Gokharu, } \\
\text { Sarata' }\end{array}$ & $\begin{array}{l}\text { Fruit powder is taken with milk orally daily to cure urinary } \\
\text { disorders. }\end{array}$ \\
\hline 24 & $\begin{array}{l}\text { Tridax procumbens } \\
\text { Linn. }\end{array}$ & Asteraceae & $\begin{array}{l}\text { 'Kutkuti, Dagadi } \\
\text { Pala }\end{array}$ & Fresh leaf paste is given in boils, cuts and wounds. \\
\hline 25 & $\begin{array}{l}\text { Withania } \\
\text { somnifera (L.) Dunal }\end{array}$ & Solanaceae & 'Ashavagandha' & Root powder used as tonic. \\
\hline
\end{tabular}

\section{ACKNOWLEDGEMENTS}

The authors, acknowledges their sincere and grateful thanks to Dr. L. K. Shitole, Principal, E. S. Divekar College, Varvand,
Tal. Daund, Dist. Pune for their constant encouragements. They are also thankful to authorities of Department of Botany, Savitribai Phule Pune University, Pune and Botanical Survey 


\section{Indo Global Journal of Pharmaceutical Sciences, 2019; 9(2): 69-72}

of India (BSI), Western circle, Pune for their valuable guidance, constructive suggestions and laboratory facilities. The authors are also grateful to the farming community and local traditional practitioners for their kind cooperation in providing information on the medicinal uses of the weed species during the field survey.

\section{REFERENCES}

1. Adlakha, P. A., A. K. Shrivastava, S. S. Shirohi, \& V. K. Sharma, 1971. Weed Flora of Ludhiana, India. J. Weed Sci. 3: 37-44.

2. Bagal, J. G., S. S. Deokule and Ghalme, R. L. 2012. Assessment of floristic diversity of Daund Tahsil from Pune district (M.S.) 'Bionano Frontier' Vol-5(1): pp 63-65.

3. Bhattacharya,D. K. and P. C. Borah, 2008. Medicinal weeds of crop fields and role of women in rural health and hygiene in Nalbari District, Assam. Ind. J. Trad. Knowl. Vol 7(3), pp501-504.

4. Chakravarti, A. K. 1957, Weed flora of paddy fields of West Bengal, Indian Agri. I (1), 19-26.

5. Cooke T. (1901-1908). The flora of presidency of Bombay. Vol I-III, London. (Repr.ed.1958) B.S.I., Calcutta.

6. Deokule, S. S. and Kamble, S. Y. 1984. Weeds of irrigated and nonirrigated agricultural fields of Baramati area in Pune district. J. Econ. Tax. Bot. Vol 1: 9-16.

7. Hooker J. D. 1872-1897. The flora of British India, VII Vols. London.

8. Jain, S. K. \& Rao, R. 1960. A handbook of field and Herbarium methods. Today \& Tomorrow's publishers, New Delhi.
9. Mulay, J. R. and P.P. Sharma 2012. Some useful weeds from Ahmednagar District, Maharashtra, India. International Multidisciplinary Research Journal. 2(12) pp 05-08.

10. Oudhia, P. 2001, Medicinal weeds in Banana orchards: A Boon for small farmers of Chhattisgarh (India). Agri. Sci. Digest 21 (4), 267-268.

11. Prayaga Murty P. and M. Venkaiah 2011, Biodiversity of Weed species in crop fields of North coastal Andhra Pradesh, India. Ind. J. Fund. and Appl.. Life Sciences Vol 1(2), pp.59-67.

12. R. Rex Immanuel and L. Lyla Elizabeth. 2009. Weeds in Agroecosystems: A source of medicines for human healthcare. 'International Journal of Pharma Tech Research' Vol.1, (2), pp 375385 .

13. Sahu, Pankaj Kumar and Shrivastava Atul, 2010, Medicinal utilities of weed flora of agriculture field of JNKVV; Jabalpur, Int. Journal of Pharmacy and life sciences. 1(8): 448-450.

14. Sharma, B. D., Karthikeyan, S. and Singh, N. P. (Eds.) 1996. Flora of Maharashtra State Monocotyledons B.S.I., Culcutta.

15. Singh, N. P., Lakshminarsimhan, P. Karthikeyan, S. \& Prasanna, P. V. 2001. Flora of Maharashtra State Dicotyledons. Vol (2). Botanical Survey of India, Kolkata.

16. Singh, N. P., Karthikeyan, S. 2000. Flora of Maharashtra State Dicotyledons Vol (1). Botanical survey of India, Kolkata.

Indo Global Journal of Pharmaceutical Sciences( ISSN 2249 1023; CODEN- IGJPAI; NLM ID: 101610675) indexed and abstracted in CrossRef (DOI Enabling), UGC CARE Journal List, EMBASE(Elsevier), National Library of Medicine (NLM) Catalog, ResearchGate, Publons, CAS (ACS), Index Copernicus, Google Scholar and many more. For further details, visit http://iglobaljournal.com

This is a special issue as an outcome of 'International Conference on Recent Advances in Traditional Medicine, Medicinal Plants and Phytochemistry' jointly organized by Ahmednagar College, India and AIMST University, Malaysia. Relaxation offered in journal format. 